\title{
The Problem and Countermeasure of Personnel File Administration in the Flow of Talent in University
}

\author{
Lu Jimin \\ School of Public Management, Yunnan University of Economics and Finance, \\ Kunming, P.R.China, 650221 \\ (532065727@qq.com)
}

\begin{abstract}
With the increasing trend of college talent flow, it is becoming a new serious problem in personnel file administration, also it brings some new challenges. Personal file is the important carrier and reliable source of personal information, and it plays a more and more important role in talent flow. Combined with actual work, this article gives some effective measures of personnel file administration in the flow of talent in university.
\end{abstract}

Keywords: Flow of Talent; Personnel Administration; Personal File.

\section{Introduction}

Recent years, The demand of college teachers is increasing, it also lead to a more exuberant talent exchange. This is an irreversible fact. However, the normal personnel transfer have to go through complex procedures, thus the flow of talent becomes the most convenient, the most practical, and the most efficient choice of personnel transfer. Therefore, how to solve the problem of personnel file management in talent flow has become a burning issue of personnel file administration, it also challenges the traditional modal of personnel file administration. It poses as an urgent issue to improve the personal file management of flowing talent

\section{The Importance of College Personnel File in the Flow of Talent}

The flow of talent is the significant sign of progress of social civilization. With the change of personnel system, talent flow shows its new characteristic of two-way choice and independent choice. Nowadays, college and universities usually engage teachers by testing their professional knowledge and affirming their degree. It is not comprehensive enough to show ability and all-around quality, and it is very difficult to select the best and most suitable person for the work. However, college personnel file could reflect the overall situation of flowing talents. The personnel file contains all the information about their experience and all-around quality. It is a important basis of using personnel properly, and a helpful tool to select talent. Therefore, normative college personnel file administration is helpful to improve the credibility of personal information, and makes a easier way to select useful people for employers. According to the information in personnel file, employing unit could find the people they need, give full play to people they hire, and promote the development of the cause.

\section{The Personnel File Problem Created by the Flow of Talent}

The archives administration of the flowing talents in colleges and universities has an important basis and credentials to promote the rational flow of talents, reasonable configuration and use, but it still exists ideological understanding, system, methods and the contents of information problems in practice, as following:

\subsection{File Holding Make More People Abandon Their Archives.}

In recent years, higher education developed very quickly. Many colleges improve their competitiveness by merging. The shortage of high-level talent is the major problem many colleges and universities are faced. To keep talents, some of colleges make rules to limit teachers flow. For example, they may provide that, Doctors and Masters need to work for many years to transfer, or they need to work for many years to get academic titles and so on. When this people try to find the other job somewhere else, in order to protect their own interests, the primary colleges and universities usually carry out the policy of "no release, no relationship transfer, no file", and use this policy to limit high-level talent to leave. However, most of the people does not give up their chance to leave. No matter how hard it is, they still want to find their better job, so they give up their file and go. 
Now, the number of people without file is increasing.

\subsection{The Unregulated Flow of Personnel Makes More "Rebuild File"}

It is the normal rule that the files always go with individuals. As the epitome of one's personal life. Personnel file is like their "second life", but it has experienced a great impact of market economy. "Human resource is the first resource", it has become the common view. For their long-term development, college and universities enhance to attract high-level talents. Some of colleges open the "easy access" to the people cannot transfer normally. Based on the individuals have, they rebuild their file. This vicious competition caused by the irregular flow of talent make more and more people have a rebuild file.

\subsection{Talent Flow Caused the Personnel File Content is not Complete}

Under the background of talent flow, college teachers flow frequently. It usually happens that, once the cadre or teacher move their position, that part of personnel file is missing. It cause that personnel file mostly show the situation in the past, not the recent situation. The information about individual's ability and specialty collected is not comprehensive, or not timely. All these problems make personnel file can not reflect individual's real record, and weakening the evidential function of college personnel file.

\section{The Solution of Flow Talent Problem in the Personnel File Management}

In order to adapt to the rational flow of talents, meet the needs of social development, establish the suitable personnel file administration, and make personnel file work for people properly, we should put emphasis on the improvement of the following aspects.

\subsection{Update the Concept of Personnel File Administration}

As the service of basic unit personnel management, the traditional idea of personnel file administration was reasonable in the past. However, this service concept is obviously questionable. The problem is under this service system, the traditional personnel file will certainly become the way to block personnel transfer, the obstruction of talent flow. Those old concept policies will face the impact of personnel "easy access". This restriction measures will lose its effect. Once individuals leave the primary college, the personnel file will their meaning. According to that, we have to renew the concept of personnel file administration, make the personnel file work for personal management, and work for development of talent.

\subsection{Enhance the Legal Sense of Personnel File} Administrators

It is an important principle that one people has only one file. They can rebuild file only when archives are lost or damaged. Some colleges open "easy access" for the high-level talent who cannot transfer their file. The "file rebuild", in order to recruit talent, is obviously not allowed in national file management rule. The authenticity and reliability of personnel file is difficult to guarantee. Fake degree and diploma, fake certification, false academic achievements, false documents and material events occur frequently. Moreover, some high-level talents use this opportunities to take advantage of legal loopholes to get better treatment and salary. According to The Archives Law, as a personnel file administrator, it is the responsibility to study the laws and regulations of archives management, supervise the units and individuals for file rebuild, and liable for their action. Personnel file administrators should possess higher political quality, work scrupulously, improve professional ability, doing personnel archives collection, identification, collation and archiving in strict accordance with the "Regulations" and "cadre archives filing rules", being a good guard of personnel information. Units and personnel department should support and help personnel file administrator to regulate the file creation, guarantee the authenticity and reliability of archives, guard the seriousness of the file administration system consciously, and implement the rules and regulations of the national personnel policy strictly.

\subsection{Expediting the Process of Social Management of Personnel File}

With the reform of personnel system, and the establish of the social management of personnel file society, management the personnel files of the imported doctor, Professor, high-level talent in the services (local talent exchange center). Getting the personnel file and colleges separated completely, and making a relatively simple relationship between people and University. thus, to make people really belongs to the state and society, to make "unit talents" become to "social talents". To establish a social management mode of personnel file, unified personnel agency and professional standards of management. it not only eliminates the trouble of archives management in Colleges and universities, but also to avoid the drawbacks of file rebuild. Also, the problem of "separated files", "abandoned 
files", "dead files" will have been solved, and realized the talents resources information sharing.

\subsection{Establish the Information System of Flowing Talent Personnel File}

First of all, the establishment of college personnel file database. The college personnel file database is a fast way to provide information services, expand the employing channel, exert file value, achieve the national macro-control of human resource. It is also the premise of the personnel file information network system. Colleges and universities are the highly centralized area of excellent talents, experts and scholars. Personnel files are the important sources that college organizations and personnel departments manage personnel. It is the important basis to understand the college personnel actually, and comprehensively. Make the college personnel files digitized, translate it to "live" information, and establish powerful database, as the service of the flow of talents. It is also conducive to do the statistical analysis and quantification work of personnel. Secondly, the establishment of personnel files network platform. As a training organization, college is a place that personnel exchange complexly. The informatization of personnel file is the inevitable requirement. The computer management of archives can not only stay in the level of management in a single computer. File management departments should make full use of modern ways, computer technology, network communication technology to establish a regional, vocational, and national information network of personnel archives. As a official information network, it will not open for the society in principle. It will only open for the authorized units(or individuals). Though the licensing network, authorized units could find the personnel file information expediently and quickly. In this way, it will not only improve the efficiency and quality of personnel file management, but also enhance the value of the personnel file, expand the use range. Moreover, it will realize the target of "information sharing". Thirdly, building the security system of college files, ensure the integrity of the personnel file, to achieve the requirement of security, and confidentiality

\subsection{Improve Collection Work, Enrich and Perfect the Personnel File Contents}

Because of the frequency of talents flow, and the dispersion of personnel, It has brought some difficulties in the collection, identification, filing etc. According to the practical problems of personnel archives collection difficulty, we can consider to take the following measures. Firstly, establish a flowing talent files collection network, and ensure that personnel archives enjoy better channels. To ensure the collection of materials timely, accurately, and completely, familiar with the file material collection scope, filing requirements. According to the rules and characteristics of personnel archives materials, collect materials timely to prevent content missing problem in talent flow. Secondly, establish and improve the personnel files archiving system, improve the management and supervision over the archive work, Keep no overstocking, no losing, accurate, ensure the personnel archives collection work timely and accurately. Thirdly, establish personal credit files, so that not only colleges and universities could fully understand the basic situation and work performance of personnel, but also the credit files could restrict the moral behavior of talents. It will make archives better service in the management, instead of a block of talents flow, and solve the recent problem of "abandoned files", "dead files" in personnel file administration so that enhance the value of personnel files, make the personnel archives become the introduction letter for individual, and the instructions for the employer. Fourth, to establish archives personnel performance, rich flow of personnel archives information content. It has lost its real meaning that the traditional personnel file records of many content, but many new contents which met the need of the era have not been recorded, that result in it can't give full play to the role and low utilization. Therefore, according to the need of the talent exchange, we need set up "talent performance file" as soon as possible.The talent performance archives not only records all the personal information , but also get the professional certification from the authoritative institution who can certificates the individual education, work experience and professional credibility certification, and issues the "individual performance integrity report". It not only make up for the deficiency of the traditional personnel file, and also provides a more intuitive and comprehensive understanding of the comprehensive quality of talent to employer. It can attaches great importance to the understanding of personnel to be employed now and the past, further improves the utilization value of current personnel files, held "import clearance on talent selection for employer.

\section{Conclusion}

All in all, it should improve the management concept of traditional personnel file, to face the challenges of traditional management of personnel archives because of the talent flowing generally and regularly, and should promote all-round development. For this purpose, the 
archives administration departments at all levels shall cooperate actively with the human resource department, to explore a new path under the new situation to carry out the work of personnel file services, so as to improve the management system of the traditional personnel file based on the practice continuously, in order to promote the development of the personnel archives work.

\section{References}

[1] Ouyanghuafeng, The conception of Chinese personnel archives information service network in talent flow environment,[D] thesis, Renmin University of Guangxi. 2009 (8).

[2] DuYuLan, Newproblems and countermeasures of talent flow brings to the management of personnel archives. Beijing file. 2012 (6)

[3] LingYuHua, problems and countermeasures of talent flow brings to the management of personnel archives.[J] Lantai World, 2005 (2).

[4] Zhu Bin, From the Mobility Phenomenon to See the management of Our Country's Personnel File in New Period [J] Technology Market Economy, 2009 (7)

[5] Deng BaoHu, The Research of the Personnel File Management Based on the Mobility of the BeiBuGulf Economic Zone [J] LanTai World, 2010 (9)

[6] Wang Liming, The Study of the Personnel Archives Management under the Background of Talent Flow. [J] Theory Research of Labor Union, 2009 (4)

[7] NiLiJuan, The Thinking about Mobility Caused by the Problems of Personnel File Management [J] Archives Science Bulletin, 2008 (1)

[8] WuXiaoPing, The Study of the Role of Personnel File in Talent Introduction [J] Intelligence Development of Science and Technology and Economy. 2005 (11)

[9] BaoChunYan, College Personnel Files in the Talent Introduction to Rebuild Discussion [J]. BingTuan Education College Journal. 2010 (2) 